\title{
Evaluation Grid for xMOOCs
}

\author{
http://dx.doi.org/10.3991/ijet.v10i4.4653 \\ Mohammad Khalil, Hubert Brunner, Martin Ebner \\ Graz University of Technology, Graz, Austria
}

\begin{abstract}
Massive Open Online Courses, shortly MOOCs, are a phenomenon nowadays. The number of courses is worldwide steadily increasing since Sebastian Thrun has offered a free online course for more than $\mathbf{1 0 0 . 0 0 0}$ students [25]. Nowadays, decision makers and students as well as lecturers are asking about the quality of such courses. After a live experiment on 15 randomly chosen courses and a brief literature review, we discuss the possibility of finding an evaluation grid for $x$ MOOCs. The finally suggested criteria can be used now for future investigations.
\end{abstract}

Index Terms-Evaluation, MOOC, Online Courses

\section{INTRODUCTION}

There are several platforms with hundreds of courses available - so called MOOCs - on the internet educating students from all over the world. However, courses vary arbitrarily on quality. Our study seeks to provide the minimum requirements that must be taken into account by decision-makers in order to detect the quality with a special eye on didactics of existing xMOOCs as well as the requisites to develop a new massive online course. The aim of this research is to gather experience with the didactics of xMOOCs on several levels and to understand the underlying structures and concepts. We will investigate the temporal sequence of instructions, the interaction with the learning materials, the recording of the activities in the learning units and the interaction with the learning group in XMOOCs.

\section{A. Defining MOOCs}

MOOCs (Massive Open Online Courses) are treated as high-quality, affordable and integrated courses in everyday life (higher) education [32]. From a technical point of view, open and global online courses can be easily attended with rather little effort by the huge number of students who are willing to participate. Students only need an internet connection to start learning. MOOC is the abbreviation of four letters. These letters stand for: Massive: Refers to large in scale, amount or degree. In which the number of participants exceeds the so-called Dunbar's number [31]. The Dunbar number describes the cognitive limit to the number of social relationships with other people [7]. Open: The openness of MOOCs usually refers to the free access to online courses and learning materials. Learners can participate in a course without the fulfillment of other formal requirements or other additional restrictions. Thus, learners can access the courses and the education materials whenever and wherever they like [11]. Online: The management, the information system as well as the course itself are exclusively online. The communication between the course participants and the learning contents takes place via a specially accredited course that is available online and introduced as a web page [31]. Course: The course can be summarized as a collection of learning materials that are being introduced by teachers in a form of a program. These courses have usually a predetermined start date and end date [27]. Courses could be taught by more than one teacher according to the content itself and the online course provider [31].

\section{B. Types of MOOCs}

On the Web, There are a variety of MOOC types available by different providers. Siemens distinguishes, for example between cMOOCs, xMOOCs and quasi-MOOCs [27]. The idea of cMOOCs is basically about knowledge and knowledge construction by self-organized networks [31]. cMOOCs are based on phases of an iterative process "Aggregate, Remix, Repurpose \& Feed Forward" [18]. Through this process, the learners in cMOOCs produce and reflect their content and share their new knowledge [1]. Moreover, the learning environment is created by the learners themselves [24]. The "c" in the cMOOCs comes from the roots of the underlying learning theory of connectivism [26]. In contrast, xMOOC is an online mass course with a strongly predetermined learning path, communication tools and assignments [31]. The prefix " $x$ " finds its origin afford by the famous universities such as Harvard and Stanford and serves as the abbreviation: "extended" [5]. Online platforms providers started to distribute additional information, learning resources and activities to lectures, which made these courses open and easily accessible by general users [22]. Unlike cMOOCs, which focus on distributing information on networks, $\mathrm{xMOOCs}$ are based on the traditional instruction-driven principle. Information is made available via an online learning platform for a large group of students [15]. The study by Langer \& Thillosen reveals that the main tool for distributing information in xMOOCs is done by video sequences. These follow often the model of traditional lectures. Moreover, xMOOCs offer multiple-choice questions, asynchronous discussion forums and work with essays [16]. In order to make the online courses more encouraging, xMOOCs providers propose badges or certificates to students who successfully complete courses. On the other hand, Siemens defined quasi-MOOCs. He specified it as a loose collection of web-based tutorials or Open Educational Resources (OER) elements. These have neither an interaction as in cMOOCs, nor an instructiondriven curriculum as xMOOCs [27]. There are obvious common areas such as interaction between different types of MOOCs. Figure 1 shows a scheme covering intersection points between the three types of Massive Open Online Courses: a) xMOOCs, b) cMOOCs and c) the Quasi-MOOCs. 
PAPER

EVALUATION GRID FOR XMOOCS

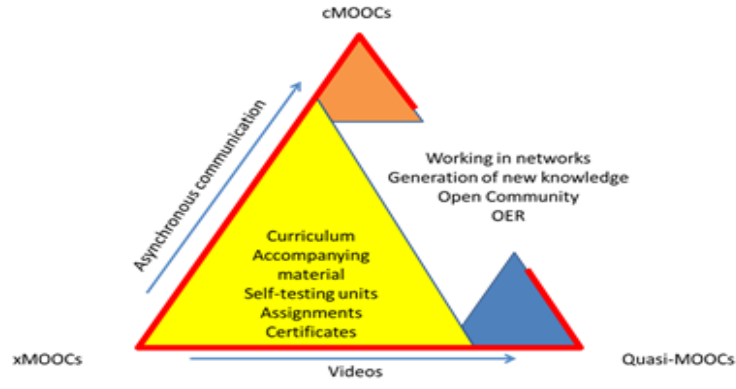

Figure 1. Intersection points between the three types of MOOCs

The criteria "asynchronous communications" can be achieved in cMOOCs according to its definition, which enhances the learners to share and reflect their learning content [2]. In accordance with the studies by [24, 31], cMOOC can have a high score of interaction criteria. Quasi-MOOCs are courses which are authored by noncertified authors [27]. Therefore, Quasi-MOOCs lack of asynchronous communication and interaction.

\section{FUNDAMENTAL ELEMENTS OF XMOOCS}

In our study, we strongly concentrate on investigating xMOOCs. Therefore, we considered an appropriate observation on xMOOCs based on various references and extracted the following crucial elements for further research in-details: Curriculum, videos, self-testing units, accompanying material, asynchronous communication, assignments, certificates, technical implementation.

\section{A. Curriculum}

Most of xMOOCs are offered as multi-week courses. The typical duration is from 6 to 12 weeks [30]. The curriculum is mainly introduced in weekly intervals $[11,31]$. Within a boundary-timing curriculum, the concentration among participants increases rapidly [30].

\section{B. Videos}

The most common way of transmitting information to students, is through lecturing videos. In addition to videos, short movies take the part of marketing the courses based on the quality of the presentation. This can be seen across different MOOCs providers.

\section{Self-testing Units}

Fundumental components of xMOOCs are quizzes and multiple-choice tests [17]. These elements are referred to as self-test units [11]. Some courses tend to provide frequent quizzes after a predetermined set of information units. Other courses, offer a full quiz after completing the whole course [28]. To enhance the social element in xMOOCs, some courses offer exchanging the quizzes information and answer them among the discussion forums [5].

\section{Accompanying Material}

In addition to the video lectures, MOOC organizers offer supplementary and accompanying material to achieve voluntary deepening purposes [31]. Accompanying material can be formed as simple texts, lecture notes, case studies or simply hyperlinks that lead to external resources. Kerres \& Preußler confirmed that the additional materials in xMOOC play a critical role and gives individuals a better support for their learning activities [11].

\section{E. Asynchronous Communciation}

Regarding the theory of media synchronicity [6], and knowledge communication [10], information and factual knowledge are well communicated through asynchronous communication [8]. The social structures among MOOCs providers are usually similar between each other. For instance, the communication between the learners and/or the teachers happens in discussion forums [31]. These discussions are used to clarify questions regarding the content of a MOOC [12]. Learners feel the positive effect when they touch the cooperation between the tutor and them.

\section{F. Assignments}

There are different methods to assess performance of participants in XMOOCs. The learners process tasks weekly, which are commonly referred to as assignments [31]. Different types of assessments are available for xMOOCs; a) Automatic assessment: This is an automated process of evaluating quizzes provided by such as multiple choice tests. b) Self-assessments: Here, the students evaluate themselves and assess each other whether they achieved the course goals. c) Peer-assessment: Here, students evaluate each other in small groups and provide feedback about their experience [11].

\section{G. Certificates}

After achieving the minimum number of points required passing in a course, students can pay to get certificates. Certificate is a motivator for many course participants [20]. Unlike cMOOCs, where the participants are motivated to extend the collective capabilities of the course's network, participants of xMOOCs are eager to achieve a good score to be able to pursue a badge or a certificate $[14,22]$. Badges can be used as a proof of performance. These were firstly introduced in order to satisfy the demand for certificates in cMOOCs. With online badges, student may show his/her achievements publicly [4].

\section{H. Technical Implementation}

There are some requirements that must be met for the technical implementation of xMOOCs such as; quizzes functionality, navigation based on the weekly courses principle, powerful search function in the discussion forums, availability of social media components, assurance of videos accessibility on peak hours, as well as the representation of the learning progress and the generation of certificates [19].

\section{RESEARCH DESIGN}

In this study, the fundamental elements of xMOOCs are refined. Through our active observations of different xMOOCs from multiple providers, characteristics of the basic instructional elements of xMOOCs are determined. We divided them into subcategories and presented criteria in order to clarify the main categories which exist in xMOOCs. In this research study, different types of methodologies are used to reveal and evaluate the upcoming results. These methods are: qualitative content analysis, personal observations, document analysis and experts opinions. In the period of three months, an observation of 15 courses from 12 xMOOCs providers has been carried out. We applied different types of criteria for examination purposes. 


\section{A. Document Analysis}

Through document analysis, we examine the relevant contents of xMOOCs [23]. xMOOC's tutor provides instructions to the learners in different ways such as emails with different instructions, motivational information and reports before, during and after the course start-off. During courses, assignments and general discussions are exchanged using documents, forums, and video's comments. This data shed light on the entries made by learners about the course subject and the learning environment in general. Contents of forum threads and the main difficulties learners post in discussions have been traced. Furthermore, analysis on the forum's topics and their frequency has been performed.

\section{B. Observations}

As test learners, we observed 15 courses of xMOOCs. Through a brief looking at the learning contents, participation in forum discussions as well as resolved assignments and tasks, all steps and difficulties faced during the observation were documented. Additionally, the interactions and discussions between teachers and students in the atmosphere of learning environment were assessed. Passive participation is used in some courses and observations of similar courses were compared together to enhance the results [21].

\section{Data Collection}

In order to collect data, we surveyed courses presented by different xMOOCs providers on a weekly basis; this is due to the common way of presenting courses. The study includes 15 courses from 12 xMOOCs provider addressing different topics. Table I shows the studied courses and their providers.

From our point of view, the courses design is similar across all xMOOCs providers. Data was collected according to curriculum and time constraints. We comprise all the time limits, deadlines, dates and documented the composition of the video lectures, supplementary materials, and quizzes. As a part of this survey, the interaction between course participants, course administrators, tutors and assistants as well as forums activity were documented and studied.

Being in a role of a student in these courses, we watched the educational videos, attended courses and resolved quizzes. Within the personal participation, we compared between workload and the provided learning content. We posted in forums and recorded the response time from students, teachers and teacher's assistants. Additionally, we looked into visualizations and progress in courses. The time and efforts needed for quizzes, and how hard they were to solve have been all documented. An important aspect for attending in XMOOCs is the temporal components. We distinguished between courses in respect to the time boundaries and the participation rate.

\section{FINDINGS}

During our research studies on xMOOCs, we become familiar with the fundamental elements of the provided courses. This study comes up with different criteria to differentiate between courses. We considered the common dilemmas of xMOOCs and cMOOCs to classify our criteria into categories and subcategories [29].

\section{A. Categories}

Table II lists these subcategories and the criteria we specified after a careful literature study and observation of different xMOOCs on different platform.

We categorized xMOOCs into three main parts according to literature study and our observations. Some subcategories are missing, in our case; we were not able to measure some criteria, such as learner's satisfaction and the dropout rates [13].

\section{B. Weights}

Each criterion was scaled from 2 to 5 according to the didactic dimension- model by Baumgartner as follows [3]: (a) Grade "1": Very clear. (b) Grade "2": Clear. (c) Grade "3": Sufficient. (d) Grade "4": Unclear. (e) Grade "5": Non-existent. By comparing XMOOC with each other, we introduce weights for the specified criteria as shown in table III. The weights were determined in regards to their importance and relevance. Each weight expresses how im-

TABLE I.

OVERVIEW OF COURSES' NAMES AND XMOOCS PROVIDERS

\begin{tabular}{|l|l|}
\hline \multicolumn{1}{|c|}{ Course Provider } & \multicolumn{1}{c|}{ Course Name } \\
\hline Moodle & Learn Moodle \\
\hline Coursera & Learn to Program: The Fundamentals \\
\hline Coursera & Foundations of Virtual Instruction \\
\hline OpenCourseWorld & Learn how to lead \\
\hline Udacity & Introduction to Computer Science \\
\hline edX & Introduction to Biology - The Secret of Life \\
\hline Canvas Network & $\begin{array}{l}\text { College Foundations: Reading, Writing, and } \\
\text { Math }\end{array}$ \\
\hline Canvas Network & Exploring Engineering \\
\hline openHPI & In-Memory Data Management 2013 \\
\hline NovoEd & Technology Entrepreneurship Part 1 \\
\hline Open2Study & Concepts in Game Development \\
\hline Standford OpenEdX & SciWrite: Writing in the Sciences \\
\hline Standford OpenEdX & Solar: Solar Cells, Fuel Cells and Batteries \\
\hline Waikato University & Data Mining with Weka \\
\hline University of Amsterdam & Introduction to Communication Science \\
\hline
\end{tabular}

TABLE II.

CATEGORIES, SUBCATEGORIES AND CRITERIA OF XMOOCS

\begin{tabular}{|c|c|l|}
\hline Category & Subcategory & \multicolumn{1}{|c|}{ Criteria } \\
\hline \multirow{5}{*}{ System } & General & $\begin{array}{l}\text { Course Content, Conditions of partic- } \\
\text { ipations, certificates }\end{array}$ \\
\cline { 2 - 3 } & Information & $\begin{array}{l}\text { Requirements, target Group, learning } \\
\text { objective, workload }\end{array}$ \\
\cline { 2 - 3 } Interaction & User Interface & $\begin{array}{l}\text { Courses clarity, availability and } \\
\text { durability forums searching feature }\end{array}$ \\
\hline \multirow{5}{*}{ Contents } & $\begin{array}{c}\text { Nature of Infor- } \\
\text { mation }\end{array}$ & $\begin{array}{l}\text { Emails prior to the course, emails } \\
\text { during the course }\end{array}$ \\
\cline { 2 - 3 } & Interactivity & $\begin{array}{l}\text { Interactive elements, forums activity, } \\
\text { replies intensity, course activity, } \\
\text { motivations }\end{array}$ \\
\cline { 2 - 3 } & $\begin{array}{c}\text { Asynchronous } \\
\text { communication }\end{array}$ & $\begin{array}{l}\text { Average response time, teachers' } \\
\text { reply and assistance, invitations }\end{array}$ \\
\hline & Media elements & $\begin{array}{l}\text { Video duration, scripts and docu- } \\
\text { ments, download feature }\end{array}$ \\
\cline { 2 - 3 } & Evaluation & $\begin{array}{l}\text { Self-study plans, self-assessment, } \\
\text { quizzes level, transparency, assign- } \\
\text { ments level, learning strategy, learn- } \\
\text { ing experience integration }\end{array}$ \\
\hline
\end{tabular}


portant and relevant one criterion is in a successful course. Crucial elements were assigned with a very high weight; medium weight was assigned for criteria that support the fundamental elements. Low weights were assigned to useful extensions criteria. During our observations, and the literature review study, we categorized knock-out criteria from the set of previous described subcategories in the next section. In table III, Weights were assigned to each subcategory criteria. The sum of weights per category is 100 points. Weights range is between 3 to 16 , the higher its weight, the more important the criterion affects. Knockout criteria were the highest in weights.

\section{Knockout Criteria}

Figure 2 shows the knockout criteria, which were defined due to their crucial role in Table III.

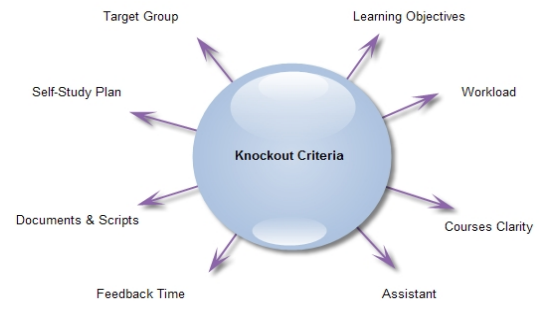

Figure 2. Overview of the Knockout Criteria of xMOOCs

The definition of the target group is essential for each xMOOC. Each xMOOC has to specify the target students who will take apart [31]. A clear learning objective facilitates the right selection of the large xMOOC offer [5]. A good planning of the workload and the required efforts such as "This course needs 5 hours/week" is an important issue. Courses with high workload have a higher dropout [9]. Course clarity was added according to [19]. Assistance to students who need help has been variously discussed as a crucial criterion in xMOOCs in [5, 16, 29]. Quick feedback in the forums is an important factor for all participants [31]. All xMOOCs providers have to make teaching materials such as scripts and documents accessible any time [11]. Finally, the ability to self-study and to plan the learning activities is essential according to [22]. The knockout criteria are assigned a high priority when grading each course of the xMOOCs in our experiment.

\section{Final Results}

Figure 3 shows the evaluation of the 15 courses from 12 different xMOOCs providers. The figure depicts a 3D graph of the courses containing each category and the final evaluation. The $\mathrm{X}$-axis shows course names while the $\mathrm{Y}$-axis shows our grading evaluation. The grading evaluation is the accumulative summation of points from each subcategory criteria. The following formula is used to get the percentage rate of each subcategory criteria:

\section{Criterion Point $=$ Criterion Weight $-(($ Grade -1$) *$ $25 \% *$ Criterion Weight)}

All tested courses share high level system features such as: offering certificates, defining the target group and clarifying the courses' content. We found four courses that have a clear declivity within the interaction category; "OpenCourseWorld: Learn how to lead" is one of the examples, where no informative emails were sent to students and a poor tutoring assistant. Additionally, it is notable that the Content category revealed an average high score in all courses.
TABLE III.

CATEGORIES, SUBCATEGORIES AND CRITERIA OF XMOOCS

\begin{tabular}{|c|c|c|}
\hline Criteria & Activity & Weight \\
\hline \multirow{8}{*}{$\begin{array}{l}\text { System } \\
\text { Criteria }\end{array}$} & Learning Objective, Workload, Target Group & 15 \\
\hline & Course clarity & 14 \\
\hline & Forums searching & 11 \\
\hline & Requirements & 10 \\
\hline & Course content & 8 \\
\hline & Certificates & 5 \\
\hline & Availability \& Durability & 4 \\
\hline & Conditions of participation & 3 \\
\hline \multirow{8}{*}{$\begin{array}{l}\text { Interaction } \\
\text { Criteria }\end{array}$} & Average response time & 16 \\
\hline & Teacher assistance & 14 \\
\hline & Forums activity, Invitations & 13 \\
\hline & Emails during the Course & 12 \\
\hline & Replies intensity & 9 \\
\hline & Motivation, Interactive elements & 7 \\
\hline & Emails prior to course & 5 \\
\hline & Course activity & 4 \\
\hline \multirow{6}{*}{$\begin{array}{l}\text { Content } \\
\text { Criteria }\end{array}$} & Self-study plan, Scripts \& Docs & 14 \\
\hline & Transparency & 13 \\
\hline & $\begin{array}{l}\text { Self-Assesment, Assignments level, Quizzes } \\
\text { level }\end{array}$ & 10 \\
\hline & Average video duration & 8 \\
\hline & Download feature & 7 \\
\hline & Learning strategy & 6 \\
\hline
\end{tabular}

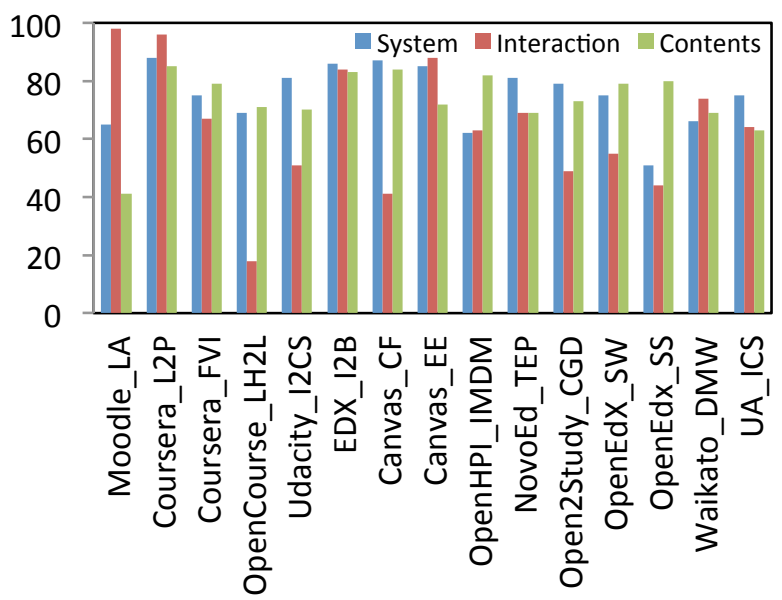

Figure 3. Categories Evaluation of the Studied Courses from xMOOCs

\section{E. The Evaluation Grid}

As the result of this research study, we present an evaluation grid that combines all the criteria of all categories. Table IV shows the grades for all criteria that have been used for all the courses of xMOOCs in this experiment. The table reveals the criteria of the main three categories: System, Interaction and Contents. By using the previous formula, a user can calculate each subcategory's accumulative points and therefore evaluate the courses. This evaluation grid supports decision makers to evaluate xMOOCs and enable them to compare different courses. 
TABLE IV.

EVALUATION GRID FOR ALL CRITERIA OF THE STUDIES COURSES OF XMOOCS

\begin{tabular}{|c|c|c|c|c|c|c|c|c|c|c|c|c|c|c|c|}
\hline Criteria & $\underbrace{\Xi}_{\Sigma}$ & 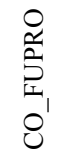 & 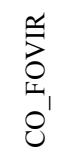 & 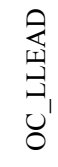 & $\begin{array}{l}\vec{n} \\
\vec{Z} \\
\rho^{\prime}\end{array}$ & 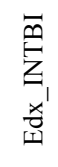 & 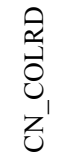 & 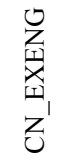 & 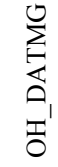 & 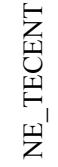 & 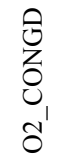 & 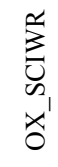 & 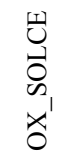 & 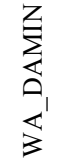 & 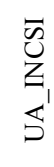 \\
\hline Course content & 1 & 1 & 2 & 1 & 2 & 1 & 1 & 1 & 1 & 1 & 1 & 1 & 1 & 1 & 1 \\
\hline Condition of participation & 1 & 1 & 1 & 2 & 1 & 1 & 1 & 1 & 1 & 1 & 1 & 1 & 1 & 1 & 1 \\
\hline Certificates & 3 & 5 & 2 & 2 & 3 & 2 & 2 & 4 & 2 & 5 & 2 & 2 & 5 & 5 & 2 \\
\hline Requirements & 3 & 1 & 2 & 1 & 1 & 2 & 1 & 1 & 2 & 1 & 2 & 2 & 1 & 2 & 2 \\
\hline Target group & 2 & 2 & 1 & 3 & 1 & 2 & 1 & 1 & 4 & 1 & 2 & 2 & 4 & 3 & 3 \\
\hline Learning objective & 1 & 1 & 1 & 2 & 2 & 1 & 1 & 2 & 3 & 2 & 1 & 2 & 3 & 1 & 2 \\
\hline Workload & 3 & 2 & 5 & 1 & 3 & 2 & 3 & 3 & 5 & 2 & 2 & 2 & 5 & 5 & 1 \\
\hline Courses clarity & 3 & 1 & 2 & 2 & 1 & 1 & 2 & 1 & 1 & 3 & 2 & 2 & 2 & 2 & 2 \\
\hline Availability \& Durability & 2 & 1 & 2 & 4 & 2 & 1 & 2 & 1 & 2 & 1 & 2 & 2 & 2 & 2 & 2 \\
\hline Forums search feature & 4 & 1 & 1 & 5 & 2 & 2 & 1 & 1 & 1 & 1 & 3 & 3 & 3 & 1 & 4 \\
\hline Emails prior to course & 1 & 2 & 3 & 4 & 4 & 1 & 4 & 2 & 4 & 3 & 2 & 3 & 4 & 4 & 4 \\
\hline Email during course & 1 & 1 & 2 & 5 & 4 & 4 & 5 & 1 & 2 & 3 & 3 & 1 & 4 & 2 & 4 \\
\hline Interactive elements & 1 & 1 & 5 & 5 & 1 & 1 & 3 & 1 & 5 & 2 & 5 & 3 & 3 & 5 & 5 \\
\hline Forum activity & 1 & 1 & 1 & 5 & 4 & 1 & 3 & 1 & 1 & 1 & 3 & 3 & 3 & 1 & 3 \\
\hline Teachers assistance & 1 & 1 & 2 & 5 & 2 & 1 & 2 & 1 & 1 & 2 & 1 & 3 & 3 & 1 & 1 \\
\hline Average response time & 1 & 1 & 1 & 5 & 3 & 1 & 3 & 2 & 3 & 1 & 3 & 2 & 2 & 2 & 2 \\
\hline Replies intensity & 1 & 1 & 2 & 5 & 3 & 1 & 3 & 2 & 1 & 2 & 3 & 3 & 3 & 1 & 1 \\
\hline Course activity & 1 & 1 & 1 & 2 & 3 & 3 & 2 & 1 & 2 & 1 & 2 & 2 & 2 & 1 & 2 \\
\hline Invitations & 1 & 2 & 5 & 2 & 2 & 2 & 5 & 2 & 5 & 5 & 5 & 5 & 5 & 3 & 2 \\
\hline Motivation & 2 & 1 & 2 & 3 & 4 & 2 & 3 & 2 & 2 & 2 & 3 & 3 & 3 & 2 & 2 \\
\hline Video duration & 1 & 2 & 3 & 2 & 1 & 4 & 1 & 1 & 3 & 3 & 1 & 2 & 1 & 2 & 1 \\
\hline Documents and scripts & 4 & 2 & 2 & 1 & 1 & 1 & 3 & 3 & 1 & 1 & 1 & 3 & 3 & 1 & 1 \\
\hline Download feature & 2 & 1 & 5 & 2 & 2 & 1 & 2 & 2 & 2 & 2 & 2 & 1 & 1 & 1 & 2 \\
\hline Self-assessment & 3 & 3 & 3 & 3 & 3 & 3 & 2 & 3 & 5 & 5 & 5 & 2 & 3 & 3 & 5 \\
\hline Self-study plan & 4 & 1 & 1 & 1 & 1 & 1 & 1 & 1 & 1 & 3 & 1 & 1 & 1 & 1 & 3 \\
\hline Quizzes level & 3 & 1 & 1 & 1 & 3 & 1 & 1 & 3 & 1 & 1 & 2 & 1 & 1 & 3 & 3 \\
\hline Assignments level & 5 & 1 & 1 & 5 & 1 & 2 & 1 & 2 & 1 & 1 & 2 & 1 & 1 & 3 & 3 \\
\hline Learning strategy & 3 & 3 & 2 & 2 & 2 & 1 & 1 & 1 & 1 & 1 & 2 & 2 & 1 & 2 & 2 \\
\hline Transparency & 5 & 1 & 1 & 3 & 5 & 2 & 2 & 3 & 1 & 3 & 3 & 3 & 3 & 5 & 3 \\
\hline Learning exp. integration & 1 & 2 & 1 & 2 & 3 & 1 & 2 & 1 & 2 & 2 & 2 & 2 & 2 & 1 & 1 \\
\hline
\end{tabular}

\section{CONCLUSION}

Massive Open Online Courses, shortly MOOCs, are a phenomenon in online education these days. Different types of MOOCs are currently available. Furthermore, there are many MOOCs providers who are offering courses to the public. Nevertheless, these courses vary in quality and the way they are offered. Our research study introduces a detailed definition of xMOOCs. We distinguished xMOOCs with cMOOCs and Quasi-MOOCs based on proposed criteria. Within a deep survey and an experiment containing of 15 courses from 12 xMOOCs providers and a deep browsing of literature study of xMOOCs, we listed some fundamental elements and knockout criteria that should exist in any online course of xMOOCs platform. We categorized these elements and classified them into subcategories. The studies courses were evaluated according to the specified criteria and our categorization of these elements. Certainly, he outcome list is not immutable, but it can be seen as a proposed structure to adapt when estab- lishing a course by any xMOOC provider. This paper makes a significant contribution to the MOOCs research field because: a) it provides a new grounded categorization of the evaluation criteria of MOOCs. b) Presents an evaluation grid than can be used to evaluate online courses of xMOOCs. Our future intent is to revolutionize the results and the experiment into an automated evaluation grid that can be used whenever xMOOCs are intended to be assessed.

\section{REFERENCES}

[1] Ahn, J., Butler, B. S., Alam, A., \& Webster, S. A. (2013). Learner participation and engagement in open online courses: Insights from the Peer 2 Peer University. MERLOT Journal of Online Learning and Teaching, 9(2), 160-171.

[2] Baker, Thomas Jerome (2012). Connectivism and Connected Knowledge: Participating in a MOOC. http://www.amazon.co.uk/Connectivism-Connected-KnowledgeParticipating-

ebook/dp/B0088DQMUS/ref=sr_1_2?ie=UTF8\&qid=1369412151 $\& \mathrm{sr}=8-2 \&$ keywords $=$ connectivism 
[3] Baumgartner, P. (2009). Developing a Taxonomy for Electronic Portfolios. In The Potential of E-Portfolios in Higher Education (S. 13-44). Innsbruck, Wien, Bozen: StudienVerlag.

[4] Baraniuk, R. (2012). Open education: One perfect storm yields three revolutions. Visiones de Telefónica.

[5] Bremer, Claudia, \& Anne Thillosen (2013). Der deutschsprachige Open Online Course OPCO12. In D. Krämer (Hrsg.), E-Learning zwischen Vision und Alltag, 64 Medien in der Wissenschaft (1527). Münster / New York / München / Berlin: Waxmann. http://www.waxmann.com/?eID=texte\&pdf=2953Volltext.pdf\&ty $\mathrm{p}=$ zusatztext

[6] Dennis, A. R., \& Valacich, J. S. (1999, January). Rethinking media richness: Towards a theory of media synchronicity. In Systems Sciences, 1999. HICSS-32. Proceedings of the 32nd Annual Hawaii International Conference on (pp. 10-pp). IEEE.

[7] Dunbar, Robin (2010). How Many Friends Does One Person Need?: Dunbar's Number and Other Evolutionary Quirks. Faber \& Faber.

[8] Eppler, M. J. (2006). The Concept of Knowledge Communication and Its Relevance to Management. Available on http://www.knowledge-communication.org/pdf/research-noteknowledge-communication.pdf

[9] Halawa, S., Greene, D., \& Mitchell, J. (2014). Dropout prediction in MOOCs using learner activity features. Proceedings of the European MOOC Summit. Lausanne, Switzerland.

[10] Kastberg, Peter (2012). Knowledge Communication Theory Revisited-from 'communicatio'to 'communis esse': paper at the IFSA conference.

[11] Kerres, Michael, \& Anabell Preußler (2013). Zum didaktischen Potenzial der Vorlesung: Auslaufmodell oder Zukunftsformat? In G. Reinmann, S. Schön, \& M. Ebner (Hrsg.), Hochschuldidaktik im Zeichen der Heterogenität und Vielfalt (79-97). Norderstedt. http://www.bimsev.de/n/userfiles/downloads/festschrift.pdf

[12] Khalil, Hanan, \& Martin Ebner (2013a). Interaction Possibilities in MOOCs - How Do They Actually Happen? (1-24). International Conference on Higher Education Development, Egypt. http://de.scribd.com/doc/134249470/Interaction-Possibilities-inMOOCs-\%E2\%80\%93-How-Do-They-Actually-Happen

[13] Khalil, Hanan, \& Martin Ebner (2013b). "How satisfied are you with your MOOC?"-A Research Study on Interaction in Huge Online Courses. World Conference on Educational Multimedia, Hypermedia and Telecommunications (Bd. 2013, 830-839). http://www.editlib.org/p/112057

[14] Khalil, H. \& Ebner, M. (2014). MOOCs Completion Rates and Possible Methods to Improve Retention - A Literature Review. In Proceedings of World Conference on Educational Multimedia, Hypermedia and Telecommunications 2014 (pp. 1236-1244). Chesapeake, VA: AACE

[15] Lackner, E., Kopp, M., Ebner, M. (2014) How to MOOC? - A pedagogical guideline for practitioners. Roceanu, I. (ed.). Proceedings of the 10th International Scientific Conference "eLearning and Software for Education" Bucharest, April 24 - 25, 2014. Publisher: Editura Universitatii Nationale de Aparare "Carol I"

[16] Langer, Volkmar \& Anne Thillosen (2013). Freie OnlineAngebote für Selbstlernende - Lebenslanges Lernen mit dem Internet. Lehrbuch für Lernen und Lehren mit Technologien, 0(0)

[17] Lipson, Kay (2013). Dealing with megaclasses in an online environment. Available on http://www.statistics.gov.hk/wsc/IPS040P3-S.pdf

[18] Mackness, J., Waite, M., Roberts, G., \& Lovegrove, E. (2013). Learning in a small, task-oriented, connectivist MOOC: Pedagog- ical issues and implications for higher education. The International Review of Research in Open and Distance Learning, 14(4).

[19] Meinel, Christoph, \& Christian Willems (2013). Das MOOCAngebot des Hasso-Plattner-Instituts. Technische Berichte des Hasso - Plattner - Instituts für Softwaresystemtechnik an der Universität Potsdam, 34

[20] Nesterko, S. O., Dotsenko, S., Han, Q., Seaton, D., Reich, J., Chuang, I., \& Ho, A. D. (2013). Evaluating the geographic data in moocs. In Neural Information Processing Systems.

[21] Nonnecke, Blair, \& Jenny Preece (2001). Why lurkers lurk. Americas Conference on Information Systems (1-10). http://bacsy.wirtschaft.fhnw.ch/iwi/publications.nsf/ae2a39a43cc0 9951c12572180036eb5b/5daca7644c019593c125722e002922b5/\$ FILE/Gg004.pdf

[22] O'Toole, Robert (2013). Pedagogical strategies and technologies for peer assessment in Massively Open Online Courses (MOOCs). http://wrap.warwick.ac.uk/54602/

[23] Punch, K. F. (1998). Introduction to social research: Quantitative and qualitative approaches. London: Sage Ltd.

[24] Robes, Jochen (2012). Offenes und selbstorganisiertes Lernen im Netz. Ein Erfahrungsbericht über den OpenCourse 2011 ,Zukunft des Lernens“. In E. Blaschitz, Brandhofer, Nosko, \& Schwed (Hrsg.), Zukunft des Lernens. Wie digitale Medien Schule, Ausund Weiterbildung verändern (219-244). Glückstadt: Werner Hülsbusch.

[25] Salmon, F. (2012). Felix Salmon on Sebastian Thrun and Udacity. Retrieved from http://delong.typepad.com/sdj/2012/01/felixsalmon-on-sebastian-thrun-and-udacity.html

[26] Siemens, George (2006). Connectivism: Learning Theory or Pastime of the Self-Amused? http://www.elearnspace.org/Articles/Connectivism_response.doc

[27] Siemens, George (2012). Massive Open Online Courses: Innovation in Education? Open Educational Resources: Innovation, Research and Practice, 2012.

[28] Schulmeister, Rolf (2012). As Undercover Students in MOOCs Lecture2Go Videoportal. Universität Hamburg. http://lecture2go.uni-hamburg.de/konferenzen/-/k/14447

[29] Schulmeister, Rolf (2013). MOOCs - Massive Open Online Courses: Offene Bildung oder Geschäftsmodell. Münster / New York / München / Berlin: Waxmann. http://www.waxmann.com/fileadmin/media/zusatztexte/2960Vollt ext.pdf

[30] Sharples, Mike u. a. (2012). Innovating Pedagogy 2012. Innovation Report. Open University. http://www.open.ac.uk/blogs/innovating/

[31] Wedekind, Joachim (2013). MOOCs - eine Herausforderung für die Hochschulen? In G. Reinmann, S. Schön, \& M. Ebner (Hrsg.), Hochschuldidaktik im Zeichen der Heterogenität und Vielfalt (4569). $\quad$ Norderstedt. http://www.bimsev.de/n/userfiles/downloads/festschrift.pdf

[32] Yuan, L., \& Powell, S. (2013). MOOCs and open education: Implications for higher education. Retrieved from http://publications.cetis.ac.uk

\section{AUTHORS}

Mohammad Khalil, Hubert Brunner, and Martin Ebner are with Graz University of Technology, Graz, Austria.

Submitted 24 April 2015. Published as resubmitted by the authors 20 August 2015. 